\title{
LATVIAN HEALTH CARE COMPANY COMPETITIVENESS DETERMINING INDICATORS AND THEIR IMPROVEMENT POSSIBILITIES
}

\author{
LATVIJAS VESELĪBAS APRŪPES UZN̄ĒMUMU \\ KONKURĒTSPĒJU NOTEICOŠIE RĀDİTĀJI UN TO \\ PILNVEIDOŠANAS IESPĒJAS
}

Inese MAVLUTOVA
Dr.sc.administr., assoc.prof., BA School of Business and Finance
Phone: +371 29524701, e-mail: Inese.Mavlutova@ba.lv
Riga, Latvia

\section{Santa BABAUSKA}

Mg.fin., BA School of Business and Finance, MBA, SBS Swiss Business School

Phone: +371 26136605, e-mail: Santa.Babauska@gmail.com

Riga, Latvia

\begin{abstract}
Changes within the circumstances of health care industry have an impact on health care company's processes and they should think about continuous improvements. The patient's appreciation, resource base of medical professionals and technological equipment level are important indicators of the health care company's competitiveness, but not all companies are taking it into account. The indicators influencing competitiveness of private health care companies from the company managers' and patients' perspective can be used in order to evaluate and to compare the health care companies' competitiveness, and to analyze competition environment of the industry.

Keywords: Balanced Scorecard, Competitiveness, Health Care Companies, Health Care Industry, Managers' Perspective, Patients'Perspective
\end{abstract}

\section{Introduction}

Health care industry affects all the society groups and industries. Competition derives from the environment where there is a rivalry for advantage. Competitiveness is an ability to compete on a certain market for beneficial conditions, competitiveness assists as a comparing tool. Latvian existing health care system is inefficient, which lowers competitiveness of the health care industry. Changes within the circumstances of health care industry have an impact on the health care company's operational processes and if the company is not able to respond timely to these changes then additional risks arise in maintenance of competitiveness that impact the overall industry's competitiveness. 
Investments in the health care industry are important for development of the society. The development stage of Latvian health care system falls behind the average development in the European Union. Competition on value is crucial for health care companies, because they have to take into account the immaterial value - the patient's health. Price level, quality of health care services and the company's image in Latvia - all these are significant factors that can influence the health care company's competitiveness both on the local and on the global markets. So companies should think strategically smarter about continuous improvements to compete in a longer run.

Results of the survey demonstrate that the private health care companies do not use the balanced scorecard in their strategic management because they have no information about it. The patient and public appreciation, resource base of medical professionals and technological equipment level are the most important competitiveness indicators from the perspective of the private health care managers. From the patients' perspective very important is the personnel competence level and company's attitude to patients. Private health care companies are not using all the possible competitiveness evaluation indicators, but the balanced scorecard can assist in increasing the company's competitiveness.

The objective of research is based on the competitiveness and balanced scorecard theoretical study and the Latvian health care industry's analysis, to point out the Latvian health care company's determining indicators of competitiveness and to indicate possibilities for improvement, on the basis of the balanced scorecard concept.

Generally accepted quantitative and qualitative methods of research in management science were used, including induction and deduction, analysis and synthesis, logically constructive and statistical methods, description and display methods of numeral information. The research of health care competition environment in Latvia, the indicators influencing competitiveness of private health care company managers' and patients' perspective can be used in order to evaluate and to compare the health care industry competition environment with other countries. The topic will continue to be relevant in the future, since all the society groups and industries are directly or non-directly influenced by the health care industry. Therefore, it will be of importance not only locally, but also globally.

In order to achieve the purpose, the comparison of theoretical aspect, Latvian health care industry and opinions of experts are researched, the applied expert method, two surveys are carried out: of the Latvian private health care company managers and patients. 


\section{The Role of Competitiveness in Development of the Company and the Relationship between Balanced Scorecard and Competitiveness}

Competitiveness is a concept, which assists as a comparing tool. In comparing, the competitiveness is popularly used on different levels; it is used on individual, product or service, company, national and global levels. As a result, it would be very hard to avoid a competition, so the solution is through managing the competition aspects, to balance them in the particular field. Changes within the health care industry conditions have an effect on the health care company's operational processes and if the company is not able to respond timely to these changes then additional risks arise in maintenance of competitiveness. Competition is a mechanism that transforms the seller and the buyer's chaotic interactions into an arranged process and determines productivity of commercial activity (4). Within the health care industry, competition at the micro level can assist in increasing the company's efficiency, profitability and market value. In accordance with the general economic theory, the customer's desires are unlimited, while resources are limited; so as soon as the desires prevail over the available resources, the competition arises to these limited resources. That is why companies should determine certain objectives to achieve and should choose between the alternatives.

The competition process promotes a better use of the company's management knowledge. From the company's perspective the competitiveness can be a benefit that increases efficiency and this can be a driving force behind the company's development. Competitiveness is a strategic management comparison tool that demonstrates existing performance of the company and further ability to compete in a certain market. Competition is about how to gain a greater market share. Usually effective use of resources is based on the company's employees, for example, on their knowledge. Competition promotes new solutions, values. Every health care company, more or less, is involved in the competition environment, but the approaches that the companies use to strive for better results in the market and to be more competitive are different. The success here is based in the tailored company strategy and the balance between available resources. However, for excellent results the companies ought to evaluate also their competitive advantages that increase the company's possibility to compete in the particular market segment.

L. E. Swayne's, W. J. Duncan's and P. M. Ginter's point of view is that "Creating competitive advantage is often a matter of selecting an appropriate basis on which to compete. Competitive advantage is the 
means by which the organization seeks to develop cost advantage or to differentiate itself from other organizations" (8). S. E. Jackson, M. A. Hitt, A. S. DeNisi, S. Angelo are of the view that "integrated resources and the difficulty of imitating them are the ultimate source of competitive advantage. Any organization that seeks a competitive advantage through human resources thus must both acquire the "right" resources and take the steps required to leverage them" (1). However the well known authors C. K. Prahalad's and M. S. Krishnan's opinion is that core drivers of the competitive advantage are connectivity, convergence, digitization and social networks, and talent and IT matters in building new capabilities and social and technical architecture of the company as well (7). As consumers and technologies advance, health care companies should develop such environment where they could co-create the value with patients. This aspect should be taken into account when thinking how to be more competitive in the health care industry.

According to the Global Competitiveness Report 2011 - 2012, one of the 12 pillars of competitiveness that drives productivity and competitiveness is Health and Primary education and healthy workforce is vital to a country's competitiveness and productivity (16). Therefore, health care companies can form a base that can provide the humans with good health. Health care sector plays a significant role when talking about the overall development of society, industry, economy, country etc.

The factors influencing the company's competitiveness can be derived from the company's internal and external environment and usually are related with the company's strengths, weaknesses and opportunities and threats. In order to be competitive, a company should operate in accordance with changes in the environment. According to Michael E. Porter, the factors that can influence company's competitiveness are mostly related with technological achievements, personnel resources, financial factors, customer satisfaction (5).

Health care organizations have employed the strategic management concepts only for the past 25 to 30 years. Indeed, many of the management methods adopted by health care organizations, both public and private, were developed in the business sector (8). Managers need to create the management system that can compete with other market players. This management system ought to be tailored so that it leads to increase in competitiveness. In theory different strategies are described, for instance, Six Sigma, Six Sigma Balanced Scorecard, Growth Share Matrix and others that can be used in order to increase the company's competitiveness.

The health care company performance in the past was more often measured only from financial and quality improvements' point of view, 
but the further described balanced scorecard has combined four perspectives that can be crucial for company to be competitive.

Robert S. Kaplan and David P. Norton published an article "The Balanced Scorecard - Measures that Drive Performance" in Harvard Business Review 1992. This created a new management system where strategic objectives of companies have been transformed into a balanced set of indicators. The purpose of this system was to balance the company's financial and non financial measurements. Balanced Scorecard (BSC) is a management system that supports the company's management in leading significant processes and changes in order to be more competitive on the market. The four balanced scorecard perspectives are reflected in Figure 1.

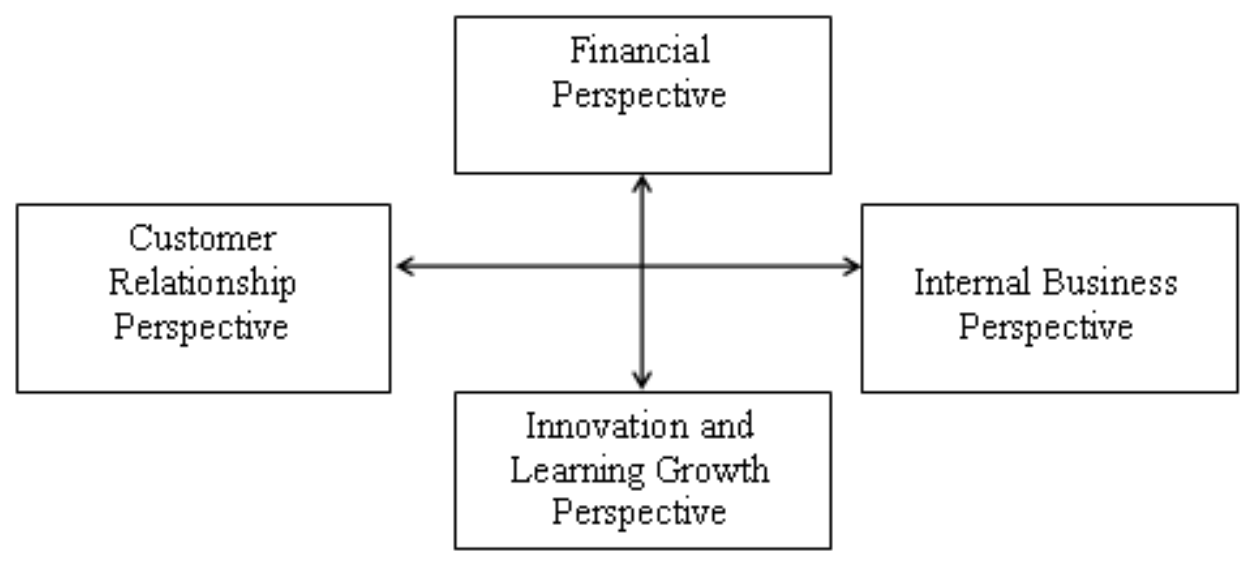

Figure 1. Balanced Scorecard Perspectives (2.)

Financial Perspective focuses on the measures of other three perspectives. By analyzing this perspective, the company's sales growth can be determined, new product, customer, market, and pricing strategy impact on sales can be analyzed. Cost reduction, productivity improvement, as well as investment strategy analysis can be performed.

Customer Relationship Perspective measures should be tailored to the company's customers who generate the greatest sales growth and are the most profitable ones, which is the indicator of new customers. Customer satisfaction, retention, customer database can be analyzed. Customer loyalty, relationship, product or service attributes, company's reputation and image are important.

Internal Business perspective is responsible for defining the processes that are the most relevant in achieving the customer and the shareholder objectives. There can be analyzed the company's process value chain as well as the processes that create the value for customers and result in financial outcomes.

Innovation and Learning Growth Perspective links the company's objectives and measures the company's learning and growth. Here the 
crucial aspects for analyzing are employees' contribution to the company, employees' satisfaction, retention, productivity, hiring, experience, education level, corporate culture, employees' learning possibilities, company's information system capabilities, and motivation.

According to the balanced scorecard, in order to manage the company's strategy, indicators reflected in Table 1 can be used.

Table 1.

Balanced Scorecard Indicators (2), (3)

\begin{tabular}{|c|c|}
\hline Financial Perspective & Internal Business Perspective \\
\hline $\begin{array}{l}\rightarrow \text { Net turnover } \\
\rightarrow \text { Production costs } \\
\rightarrow \text { Direct and indirect expenses } \\
\rightarrow \text { Amount of interest payable } \\
\rightarrow \text { Equity and borrowed capital weight } \\
\quad \text { and price for use in \% } \\
\rightarrow \text { The amount of taxes paid } \\
\rightarrow \text { Total asset value } \\
\rightarrow \quad \text { Fixed asset profitability in } \% \\
\rightarrow \quad \text { Invested capital profitability in } \%\end{array}$ & $\begin{array}{l}\rightarrow \quad \text { Digitalization level in \% } \\
\rightarrow \quad \text { The average decision-making } \\
\text { duration in days } \\
\rightarrow \quad \text { Average Debt Settlement Period in } \\
\text { days } \\
\rightarrow \quad \text { Company's provisions with } \\
\quad \text { inventory in days }\end{array}$ \\
\hline Customer Relationship Perspective & Staff training and development \\
\hline $\begin{array}{l}\rightarrow \text { Market share in } \% \\
\rightarrow \quad \text { The division of company's customers } \\
\text { in accordance with ABC method in \% } \\
\rightarrow \text { Customer satisfaction index in \% } \\
\rightarrow \text { Price level change } \\
\rightarrow \text { Amount of lost customers }\end{array}$ & $\begin{array}{l}\rightarrow \quad \text { Employee turnover } \\
\rightarrow \quad \text { The average employee length of } \\
\text { service in years } \\
\rightarrow \quad \text { Employee satisfaction index in \% } \\
\rightarrow \quad \text { Registered patent, received license } \\
\quad \begin{array}{l}\text { amount } \\
\rightarrow \quad \text { Investments in new market } \\
\text { development }\end{array}\end{array}$ \\
\hline
\end{tabular}

By measuring the above-mentioned indicators, the company can detect its advantages and disadvantages for further improvements of competitiveness. For shareholders it will allow to control and improve the company's value increasing, for management to optimize the daily processes and decision-making for future activities.

\section{Analysis of Latvian Health Care Industry}

Investment in health care is crucial to successful development of modern societies and to their political, social and economic progress (17). Through measuring financial, human and technical resources, the healthcare providers can combine these data with managerial choices, it is possible to assess and measure the performance of healthcare providers and the whole system (10). M. E. Porter and E. O. Teisberg have shown that the value based competition in health care industry has a 
significant impact, because it improves the value to customers, the quality in relation to price level (6). In health care system the trend of costs is increasing, due to ageing population and development of new treatments. Governments are trying to cope with this by improving the procedures in health care, but not the real outcomes (15).

The recent findings show that there is need of change in the frameworks of health care policy despite the fact that health level is improving globally; there still are relevant inequalities between the regions. This is indicative of incompleteness in the health care systems and inefficient use of the available resources and knowledge. The health care system ought to be adjusted to the changing environment, the increasing uncertainty, the social and demographic factors, as well as to changes in the value system.

Health systems in the European countries are of growing size and complexity, and spending on health care has never been higher, consuming an ever-increasing share of national income (14). According to the Global Competitiveness index 2011-2012, based on its $4^{\text {th }}$ pillar Health and Primary education directly by infant mortality, deaths / 1,000 live births, Latvia is ranked as $43^{\text {th }}$ among 142 economies, but according to life expectancy Latvia is ranked as $73^{\text {th }}(16)$. These figures indicate the necessity of improvements in health care. The Euro Health Consumer index 2009 divides the assessment measures in 6 sub-disciplines: patients' rights and information, e-Health, waiting times for treatments, treatment outcomes, range and reach of services provided, and pharmaceuticals. Based on this index, according to special indicators in each category, Latvia is ranked as the $31^{\text {st }}$ among 33 countries (13).

The development stage of Latvian health care system falls behind the average development of health care systems in the Baltic States and the European Union. The growth rate is slow in the industry and health care service availability is not provided in the highest quality. The gross value added of Latvian health care in the period from 2007 to 2009 had the tendency to increase, but in 2010 it decreased by 9 percentage points, which is reflected in Figure 2. 


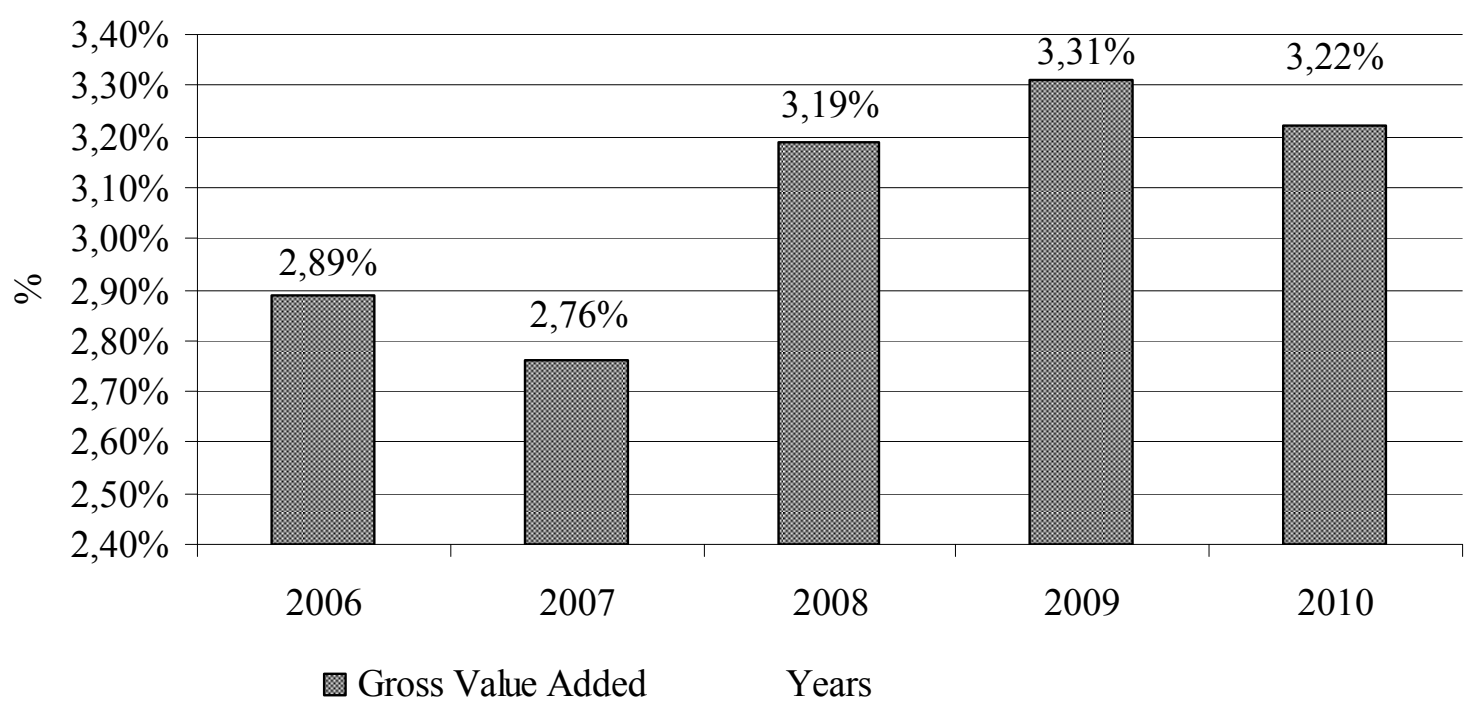

Figure 2. Gross Value Added of Latvian Health Care Industry from 2006 to 2010, in \%, Calculated at Current Prices (11)

By analyzing the health care budget, conclude can be drawn that since 2009 the health care budget has had a tendency to decrease; for instance, from 576 million Ls in 2008 it decreased by $12.5 \%$ in 2009 . The main reason has been the budget consolidation. The total allocated budget for health care can be viewed in Figure 3.

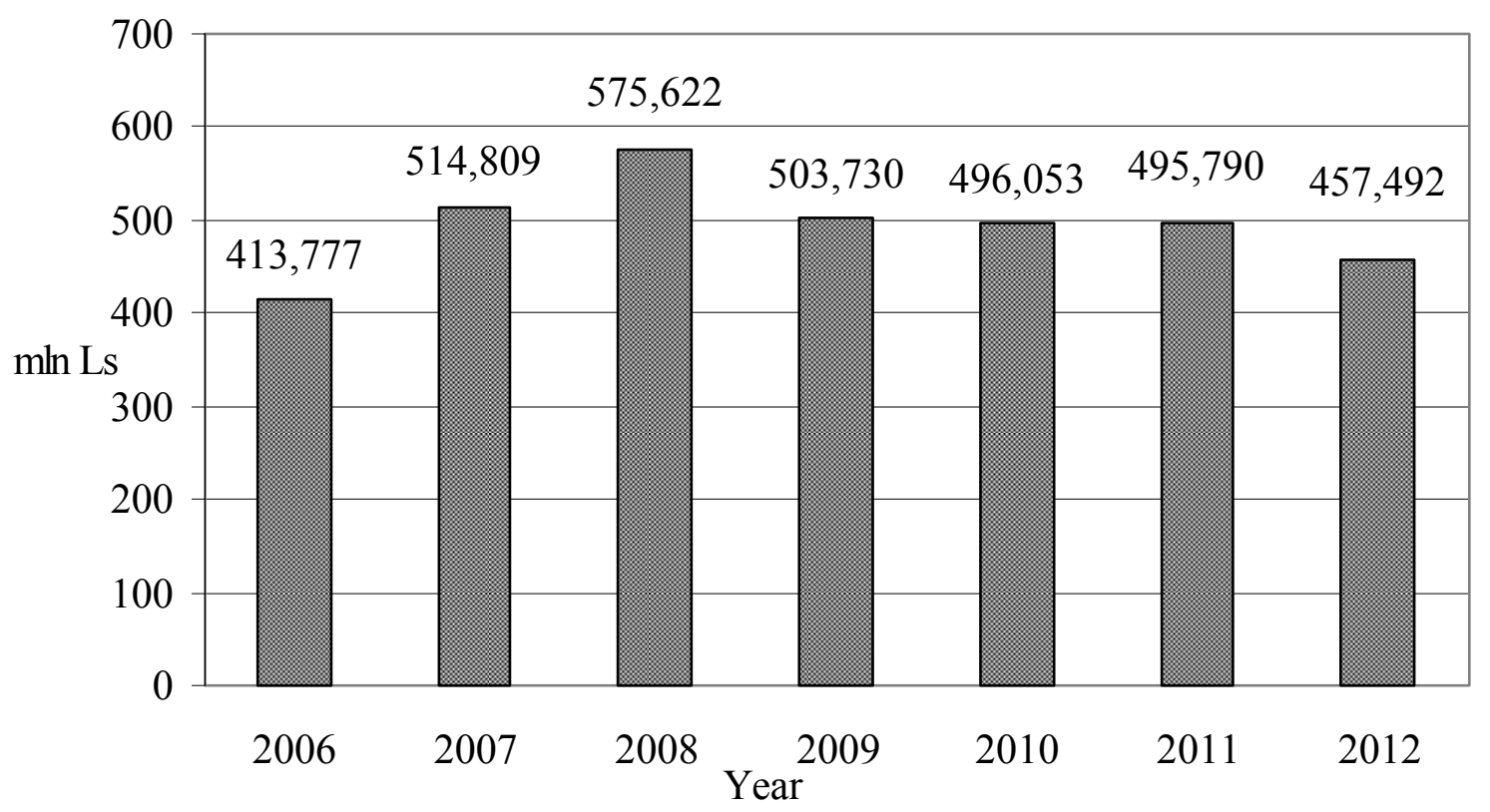

Figure 3. Latvian State Health Care Budget from the Year 2006-2012, in million Ls (12)

The basic indicators of health care in Latvia are reflected in Table 2. 
Table 2.

Basic Indicators of Latvian Health Care at the End of 2006 - 2010 (9)

\begin{tabular}{|l|c|c|c|c|c|}
\hline \multicolumn{1}{|c|}{ Indicator } & 2006 & 2007 & 2008 & 2009 & 2010 \\
\hline Physicians of all specialities & 8341 & 8014 & 8437 & 7964 & 7951 \\
\hline Residents and apprentices & 420 & 478 & 637 & 489 & 463 \\
\hline $\begin{array}{l}\text { Specialists with higher medical } \\
\text { professional education }\end{array}$ & 379 & 391 & 462 & 483 & 519 \\
\hline Nurses with higher education & 593 & 700 & 692 & 831 & 1090 \\
\hline $\begin{array}{l}\text { Medical personnel with } \\
\text { secondary medical education }\end{array}$ & 14,751 & 14,546 & 15,197 & 13,492 & 13,217 \\
\hline Hospitals & 106 & 94 & 88 & 69 & 67 \\
\hline Beds in Hospitals & 17,599 & 17,497 & 17,001 & 14,434 & 11,920 \\
\hline $\begin{array}{l}\text { Health care institutions } \\
\text { providing outpatient services- } \\
\text { total }\end{array}$ & 3183 & 3285 & 4078 & 4583 & 4756 \\
\hline
\end{tabular}

As it can be observed in the Table 2, the number of health care institutions providing outpatient services has constantly increased during the period from 2006 to 2010. The rapid increase was in 2008 and 2009, when hospital restructuring took place and the hospital amount decreased, for instance, in 2009 by 19 hospitals. This intensified the competition in private health care sector.

In order to evaluate the factors that influence the Latvian health care industry, the authors divided the forces according to Michael E. Porter 5 force model and determined the strength / significance on the industry's activities. The value scale was created, where 1 - very low, 5 very strong power. The Latvian health care industry's assessment according to expert method is given in Table 3. Bargaining power of patients has the most significant impact on the health care industry in Latvia due to patient solvency, wider choice, and because of patients' better education and knowledge of health care services.

Table 3.

Assessment of Latvian Health Care Industry based on Michael E. Porter 5 Force Model (18)

\begin{tabular}{|l|c|cl|}
\hline \multicolumn{1}{|c|}{ Force (5) } & $\begin{array}{c}\text { Strength / } \\
\text { Significance }\end{array}$ & & \multicolumn{1}{c|}{ Comments } \\
\hline $\begin{array}{l}\text { Competition } \\
\text { Intensity }\end{array}$ & 3 & $\begin{array}{l}\rightarrow \\
\rightarrow\end{array}$ & $\begin{array}{l}\text { Economic situation effects } \\
\text { Competitor amount increase }\end{array}$ \\
\hline $\begin{array}{l}\text { Bargaining Power } \\
\text { of Suppliers }\end{array}$ & 2 & $\rightarrow$ & $\begin{array}{l}\text { Requirements of advance payments } \\
\text { Offer of certain company's } \\
\text { medicaments }\end{array}$ \\
\hline
\end{tabular}


Table 3 continued

\begin{tabular}{|l|c|l|}
\hline $\begin{array}{l}\text { Bargaining Power } \\
\text { of Patients }\end{array}$ & 5 & $\begin{array}{l}\rightarrow \text { Patient solvency } \\
\rightarrow \text { Wider choice } \\
\rightarrow \text { More educated, well informed in } \\
\text { health care due to available } \\
\text { information in social networks }\end{array}$ \\
\hline $\begin{array}{l}\text { Threat of } \\
\text { Substitutes }\end{array}$ & 2 & $\rightarrow \begin{array}{l}\text { Cheaper medical services on lower } \\
\text { class technologies }\end{array}$ \\
\hline $\begin{array}{l}\text { Threat of New } \\
\text { Entrants }\end{array}$ & 4 & $\rightarrow \begin{array}{l}\text { New medical centres entering in the } \\
\text { market }\end{array}$ \\
\hline
\end{tabular}

According to opinions of the health care industry experts, the price level, the quality of health care services and the health care company's image in Latvia are significant factors that can influence the health care company's competitiveness both on the local and global markets. The health care industry competition environment has been driven by activities of the private health care companies.

\section{Results of Latvian Private Health Care Company Managers' and Patients' Surveys}

In order to find out Latvian health care company competitiveness determining indicators, two surveys of the Latvian private health care company managers and patients are carried out at the end of 2011.

One hundred fifty private health care companies from Riga were selected and the questionnaire link was sent to private health care company managers. 36 responses from the private health care company managers were received.

The survey results demonstrate that sustainable business strategy and good management skills are selected as the most important success factors because these are mentioned in $47 \%$ or 23 replies. Only $2 \%$ or 1 of the received answers stated that other factor such as price level is more important. $18 \%$ of answers mentioned uniqueness of the company's service, $22 \%$ of answers - ability to tailor to industry's trends and $10 \%$ of answers - large investments in business development. 81\% or 29 respondents evaluated the company's competitiveness, $17 \%$ or 6 respondents did not evaluate, and one respondent had no idea about evaluation in the company.

The replies to the question "Do You have information about what is Balanced Scorecard and is it used in Your company's strategic management?" demonstrate that the majority - $67 \%$ or 24 respondents, do not know what the Balanced Scorecard is, but they would like to 
know. Only 3\% say that they know what it is; however, they do not use it in their company's strategic management. $30 \%$ of respondents do not know and that is why they are not using it.

The patients' questionnaire was sent through national social network Draugiem.lv and Facebook.com. 184 responses from private health care company patients were received. Altogether $34 \%$ or 63 males and $66 \%$ or 121 females took part in the survey, the average age was 27 years, but the range of the age was between 21 and 55 .

In evaluating the indicators that influence competitiveness, the survey results show that patient and public appreciation, resource base of medical professionals and technological equipment level are the most important competitiveness indicators from perspective of the private health care managers. Detailed results are reflected in Table 4.

Table 4.

Importance of Indicators Influencing Private Health Care Company's

Competitiveness (18)

\begin{tabular}{|c|c|c|c|c|c|}
\hline Indicator & Rank & Points & Indicator & Rank & Points \\
\hline Patient and public appreciation & 1 & 112 & $\begin{array}{l}\text { Satisfaction of } \\
\text { patient needs }\end{array}$ & 5 & 159 \\
\hline Resource base of medical professionals & 2 & 120 & \multirow{2}{*}{$\begin{array}{l}\text { Health care } \\
\text { service } \\
\text { differentiation } \\
\text { level }\end{array}$} & \multirow[b]{2}{*}{6} & \multirow[b]{2}{*}{172} \\
\hline Technological equipment level & 3 & 127 & & & \\
\hline Financial factors & 4 & 143 & Cost savings & 7 & 175 \\
\hline
\end{tabular}

From the patients' perspective it can be concluded that the most significant balanced scorecard perspective is the personnel competence level and the company's attitude to patients, as can be seen in the Table 5 .

Table 5.

The Balanced Scorecard Four Perspective Significance from the Private Health Care Company Patient Point of View (18)

\begin{tabular}{|l|c|c|}
\hline \multicolumn{1}{|c|}{ Indicator } & Rank & Points \\
\hline Health care company's personnel competence level & 1 & 108 \\
\hline Health care company's attitude to patient & 2 & 148 \\
\hline Health care company's internal business organization & 3 & 268 \\
\hline Health care company's financial indicators & 4 & 276 \\
\hline
\end{tabular}

The final question was stated as follows: „In evaluation of healthcare companies, would you prefer a company that analyzes and strives to improve the four perspective indicator results, acknowledged by you as the most important ones, to your current healthcare provider?" 35 
or $19 \%$ of respondents replied that it is hard to say, 55 or $30 \%$ - they would not choose that company, but the majority or 94 respondents answered that they would prefer that company. The results show that indicators offered by the authors are important for patients in choosing private health care company. The balanced scorecard concept indicators are reflected in Table 6 that are ranged in the priority of private health care company managers' and patients' perspective.

The combined survey results show that on the basis of patient relationship the three main indicators are - accurate problem identification, service availability and quality. According to the internal organization perspective, the three main indicators are - interest in providing qualitative service, the technical level of medical equipment, and the recognition a company has received on the employee and the partner collaboration level. From the employee learning and growth perspective, the most significant are staff education and qualification, average length of employment with the company and the level of staff experience in the field. The survey results of the most significant financial indicators in private health care companies show that significant indicators are profitability ratios, net turnover and gearing ratios, while the least significant financial indicator is the balance sheet value. The survey results show that private health care companies are not using all the possible indicators for evaluation of competitiveness, as the main indicators companies use different profit and profitability ratios.

Table 6.

Balanced Scorecard Concept Indicators for the Health Care Company (18)

\begin{tabular}{|c|c|}
\hline Patient Relationship Perspective & Internal Organization Perspective \\
\hline $\begin{array}{l}\text { 1. Accurate patient problem } \\
\text { identification } \\
\text { 2. Service availability } \\
\text { 3. Service quality } \\
\text { 4. Waiting time to get to the doctor } \\
\text { 5. Service culture } \\
\text { 6. Price level change } \\
\text { 7. Time for patient spent on problem } \\
\text { 8olving } \\
\text { 9. } \text { Coputation level } \\
\text { 10. Patient satisfaction index } \\
\text { 11. Number of patients lost } \\
\text { 12. Yearly patient flow changes } \\
\text { 13. Patient categorization by stage of } \\
\text { the service operating costs }\end{array}$ & 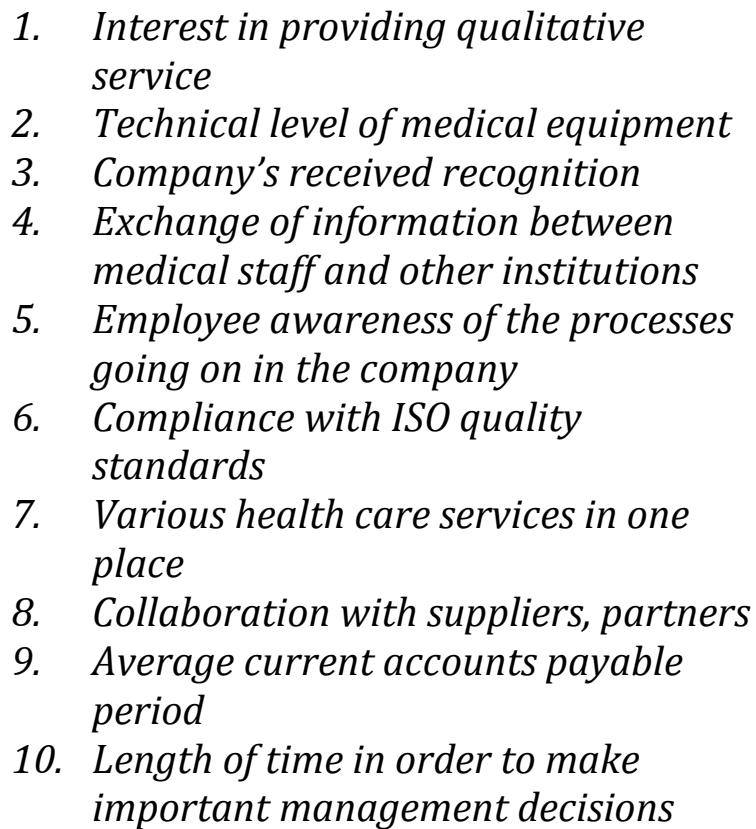 \\
\hline
\end{tabular}


Table 6 continued

\begin{tabular}{|ll|ll|}
\hline \multicolumn{2}{|c|}{$\begin{array}{c}\text { Employee Learning and Growth } \\
\text { Perspective }\end{array}$} & \multicolumn{2}{|c|}{ Financial Perspective } \\
\hline 1. & Staff education and qualification & 1. & Profitability ratios \\
2. & Staff average length of employment & 2. & Net turnover \\
& with the company & 3. & Gearing ratios \\
3. & Staff experience level in the field & 4. & Future cash flows \\
4. & Training course, seminar, & 5. & Economic Value Added* \\
& conference attendance & 6. & Liquidity ratios \\
5. & Staff turnover ratio & 7. & Shareholders' equity \\
6. & Investment in staff training and & 8. & Market share \\
& development & 9. & Activity ratios \\
7. & Average age of the staff & 10. & Total balance sheet value \\
8. & Publications by medical staff & & \\
& & $*$ & \\
\end{tabular}

In conclusion, the Balanced Scorecard can allow better organization of the health care company's work. The offered concept of competitiveness improvement possibilities can be viewed in Figure 4.

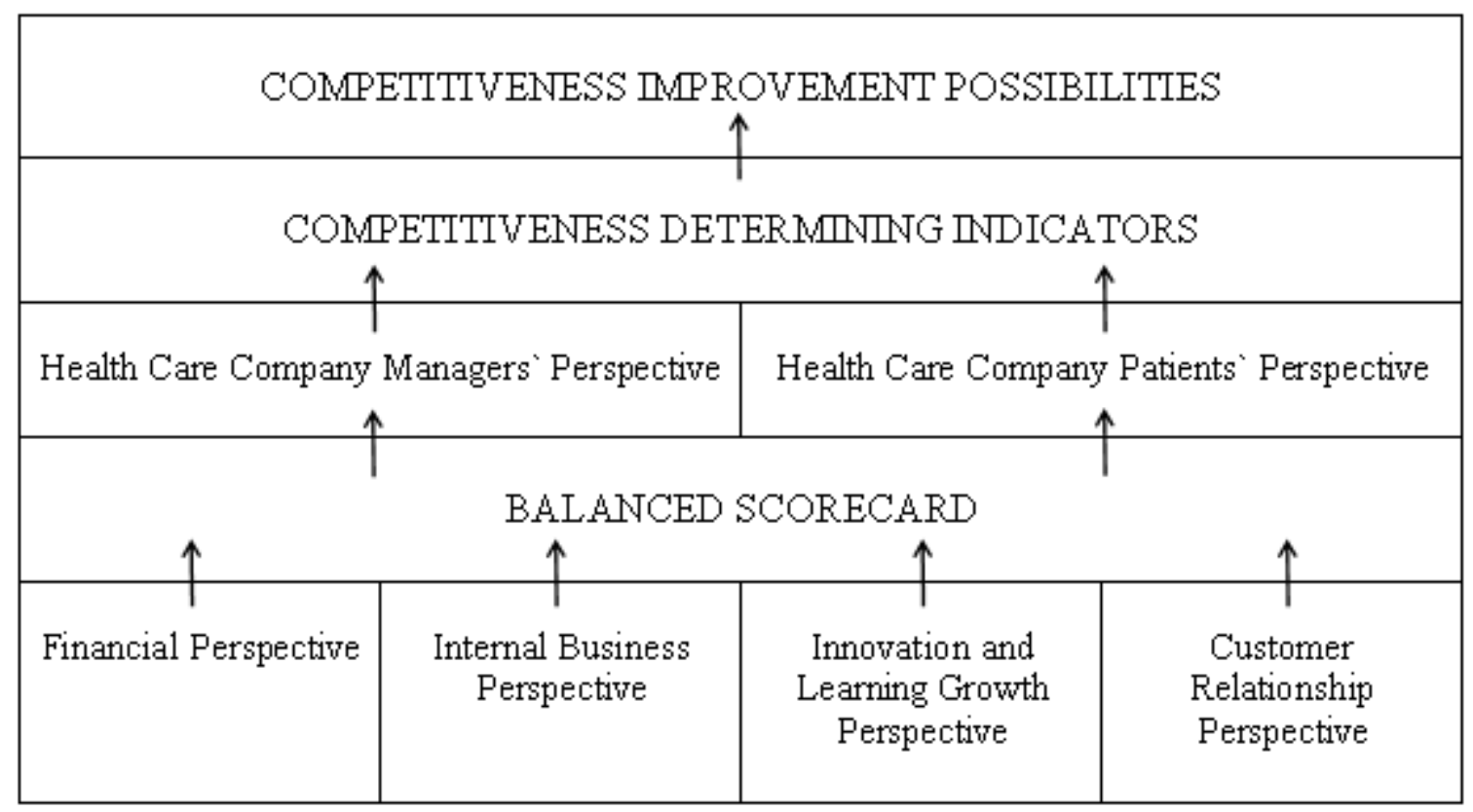

Figure 4. The Concept for Health Care Company Competitiveness Improvement Possibilities (18)

\section{Conclusions and Proposals}

The main conclusions and recommendations are as follows:

1. A global trend indicates that there is a change needed in the health care systems by refocusing emphasis on the value for patients, 
because more and more role takes the approach of the patient centric health care. The recent findings show that there is a need of change in the frameworks of health care policy despite the fact that health level is improving globally; there are still relevant inequalities between the regions. This indicates the incompleteness in health care systems and inefficient use of the available resources and knowledge.

2. Not only the market forces, but also the government regulations are very important aspects in analyzing the competition in the private health care industry. Price level, quality of health care services and the company's image in Latvia - all these are significant factors that can influence the health care company's competitiveness both on the local and on the global markets.

3. Analysis of what indicators are the most significant in evaluating the perspective of collaboration between the health care company and the patient, the private health care company managers have chosen availability of the health care company service and the patient satisfaction index as the most significant indicator.

4. Majority of those private health care company managers, whose companies have strategy and who consider strategy and management skills as the most important success factor for maintaining the competitive position, also evaluate their company's competitiveness.

5. The private health care companies should think about a valuebased competition where companies can compete in delivering better value to customer. One of the ways to deliver better value to customer is through the management of factors that are important for patients. Factors that usually create a benefit for patients are related with intangible aspects.

6. Balanced Scorecard can allow for better organization of the health care company's work due to showing those business areas, which require better strategic management. This may allow for the companies to focus on things that are the most important and to measure their success.

7. Implementation of assessment criteria's such as technological, personnel qualification and patient satisfaction level of evaluating the performance of Latvian health care companies would allow differentiating the companies in categories or levels so that the patients have the opportunity to choose the best health care provider.

8. Development of the concept for health care company competitiveness improvement possibilities can be used in Latvian 
health care industry in order to evaluate the health care company competitiveness level. Previously mentioned concept could be used in order to increase the competitiveness of Latvian health care companies, because it can add value to overall Latvian health care industry.

9. After implementation of the Balanced Scorecard concept and regular analysis of the changes of offered concept indicators and their impact on the health care company, can lead to higher competitiveness of the health care company.

\section{Bibliography}

1. JACKSON, S.E., HITT, M. A., DENISI, A. S., ANGELO, S. Managing Knowledge for Sustained Competitive Advantage: Designing Strategies for Effective Human Resource Management. San Francisco, United States of America: Jossey - Bass, A Wiley Imprint, 2003, $452 \mathrm{p}$.

2. KAPLAN, R. S., NORTON, D. P. Strategy Maps: Converting Intangible Assets Into Tangible Outcomes. Boston, United States of America: Harvard Business School Publishing, 2004, $454 \mathrm{p}$.

3. MAVḶUTOVA, I. Uzṇēmuma vērtības paaugstināšana un tā finansiālais stāvoklis. Vadībzinātne. Ekonomika. Riga: Biznesa un Finanšu pētniecības centrs, 2009. pp. $27-34$.

4. $\quad$ OḶEVSKIS, G. Uznêemējs un tirgus. Riga: Jāṇa Rozes apgāds, 2007, 220 p.

5. PORTER, M. E. Competitive Strategy: Techniques for Analyzing Industries and Competitors. New York, United States of America: The Free Press, 1998, 396 p.

6. PORTER, M. E., TEISBERG, E. O. Redefining Health Care: Creating Value - Based Competition on Results. Boston, United States of America: Harvard Business School Press, 2006, 506 p.

7. PRAHALAD, C. K., KRISHNAN, M. S. The New Age of Innovation: Driving CoCreated Value through Global Network. McGraw-Hill, 2008, 278 p.

8. SWAYNE, L. E., DUNCAN, J. W., GINTER, P. M. Strategic Management of Health Care Organizations. Oxford, United Kingdom: Blackwell Publishing Ltd., 2006, $888 \mathrm{p}$.

9. Basic Indicators of Health Care in Latvia at the End of the Year [Online]. Riga: Central Statistical Bureau [accessed 17 Oct. 2011]. Available:http://data.csb.gov.lv/Dialog/varval.asp?ma=VA0010a\&ti=VAG01.+ BASIC+INDICATORS+OF+HEALTH+CARE+SERVICES+AT+THE+END+OF+THE +YEAR\&path=../DATABASEEN/Iedzsoc/Annual\%20statistical\%20data/11.\%2 0Health\%20care\%20and\%20sport/\&lang=1

10. Europe in Figures: Eurostat Yearbook 2011 [Online]. Luxembourg, European Union: Eurostat, European Commission [accessed 12 Dec. 2011]. Available: http://epp.eurostat.ec.europa.eu/cache/ITY OFFPUB/KS-CD-11001/EN/KS-CD-11-001-EN.PDF

11. Gross Value Added [Online]. Riga: Central Statistical Bureau [accessed 27 Aug. 2011].

Available:http://data.csb.gov.lv/Dialog/varval.asp?ma=IK0040\&ti=IK04\%2E + IEK\%DOZEMES+KOPPRODUKTS+PA+DARB\%CEBAS+VEIDIEM+\%28t\%FBkst \%2E+latu\%29\&path=../DATABASE/ekfin/Ikgad\%E7jie\%20statistikas\%20dat $\mathrm{i} /$ Iek\%F0zemes\%20kopprodukts/\&lang=16 
12. Health Care Budget [Online]. Riga: Health Ministry of the Republic of Latvia [accessed 10 Nov. 2011].

Available: http://www.vm.gov.lv/index.php?id=130\&top=0

13. Health Consumer Powerhouse. Euro Health Consumer Index 2009 Report [Online]. Health Consumer Powerhouse [accessed 10 Nov. 2011].

Available:http://www.healthpowerhouse.com/files/Report\%20EHCI\%20200 9\%20091005\%20final\%20with\%20cover.pdf

14. OECD (2010) [Online]. Health at a Glance 2010: OECD [accessed 29 Sep. 2011]. Available: http://dx.doi.org/10.1787/health glance-2010-en

15. PORTER, M. E., KAPLAN, R. S. Solving the Health Care Cost Crisis [Online]. Harvard Business Publishing video interview with Kaplan, R. S. [accessed 1 Nov. 2011]. Available: http://hbr.org/2011/09/how-to-solve-the-costcrisis-in-health-care/ar/1

16. World Economic Forum, The Global Competitiveness Report 2011-2012 [Online]. Geneva, Switzerland: World Economic Forum within the Framework of the Centre for Global Competitiveness and Performance [accessed 1 Nov. 2011]. Available: http://www3.weforum.org/docs/WEF GCR Report 201112.pdf

17. World Health Organization Regional Committee. The New European Policy for Health - Health 2020 [Online]. Baku: The World Health Organization Regional Committee [accessed 30 Oct. 2011].

Available:

http://www.euro.who.int/ data/assets/pdf file/0007/147724/wd09E Healt h2020 111332.pdf

18. The research results of Latvian health care industry and health care company managers` and patients`surveys of the year 2011 carried out by the authors of the paper.

\section{Kopsavilkums}

Darba tēma ir Latvijas veselības aprūpes uzṇēmumu konkurētspēju noteicošie rādītāji un to pilnveidošanas iespējas.

Veselības aprūpe ir nozare, kura ietekmē visas pārējās nozares un sabiedrības grupas. Latvijā pastāvošā veselības aprūpes sistēma darbojas neefektīvi, kas pazemina veselības aprūpes nozares konkurētspēju. Tas liek privātajiem veselības aprūpes uzṇēmumiem uzlabot efektivitāti un kvalitāti, lai varētu būt konkurētspējīgāki.

Aktuāli ir izpētīt, kā līdzsvarotās rādītāju kartes koncepcija var norādīt uz veselības aprūpes uzṇēmuma konkurētspēju pilnveidošanas iespējām.

Darba mērksis ir, balstoties uz konkurētspējas un līdzsvarotās rādītāju kartes teorētisko izpēti, veikt Latvijas veselības aprūpes nozares analīzi, parādìt Latvijas veselības aprūpes uznēmumu konkurētspēju noteicošos rādītājus un norādīt uz to pilnveidošanas iespējām, ñemot par pamatu līdzsvarotās rādītāju kartes koncepciju.

Izmaiṇas veselības aprūpes nozarē ietekmē veselības aprūpes uzṇēmuma procesus un tiem ir jādomā par pastāvīgiem uzlabojumiem. Pacienta novērtēšana, veselības aprūpes nozares speciālistu resursi un tehnologiju aprīkojuma līmenis ir nozīmīgi rādītāji veselības aprūpes uzṇēmuma konkurētspējas novērtēšanā, bet ne visi uzṇēmumi to ñem vērā. Darbā pētīta veselības aprūpes nozare Latvijā, nozares ekspertu viedokḷi, veiktas Latvijas privāto veselības aprūpes uzṇēmumu vadītāju un 
pacientu aptaujas, lai noskaidrotu konkurētspēju noteicošos rādītājus un to pilnveidošanas iespējas.

Darbā ir secināts, ka konkurētspēja ir koncepcija, kura var darboties kā salīdzināšanas instruments, kurš palīdz veikt salīdzinājumus un pieṇemt lēmumus kā uzṇēmuma konkurētspēja var tikt uzlabota. Globālās tendences norāda, ka ir nepieciešamas izmaiṇas veselības aprūpes sistēmās, pārstrukturizējot uzsvaru uz pievienotās vērtības veidošanu pacientam, jo aizvien lielāku un lielāku lomu gūst uz pacientu virzīta veselības aprūpe.

Latvijas privāto veselības aprūpes uznēmumu aptaujas rezultāti parāda, ka uzṇēmumi neizmanto līdzsvaroto rādītāju karti uzṇēmumu stratēgiskajā vadīšanā, jo galvenokārt trūkst informācijas par to. Taču būtu jāṇem vērā, ka līdzsvarotā rādītāju karte var labāk organizēt veselības aprūpes uzṇēmuma darbību, jo parāda tās jomas, kur nepieciešama labāka stratēgiskā vadība. Latvijas veselības aprūpes uzṇēmumi arī neizmanto daudzus pieejamos konkurētspēju noteicošos rādītājus.

Darbā tiek izteikti vairāki priekšlikumi, piemēram, ieviest veselības aprūpes uzṇēmumu darbības novērtēšanas kritērijus nozarē, izvērtējot uzṇēmumu pēc tehnologiju, personāla kvalifikācijas un klientu apmierinātības līmeṇa, kas l,autu diferencēt uzñēmumus kategorijās, lai pacientam būtu iespējams izvēlēties sev pieṇemamāko veselības aprūpes pakalpojuma sniedzēju. Ieteikums ir arī attīstīt līdzsvarotās rādītāju kartes koncepcijas izmantošanu Latvijas veselības aprūpes nozarē, lai novērtētu veselības aprūpes uzṇēmumu konkurētspēju, kā arī, lai mēginātu paaugstināt to. Izmantojot līdzsvarotās rādītāju kartes koncepciju, ieteicams analizēt izmaiṇas veselības aprūpes uzṇēmumu rādītājos un to ietekmi uz uzṇēmuma attīstību.

Atslēgas vārdi: konkurētspēja, līdzsvarotā rādītāju karte, pacientu perspektīva, vadītāju perspektīva, veselības aprūpes nozare, veselības aprūpes uzñēmumi. 